\title{
Research on Internet Financial Consumer Rights Protection in China
}

\author{
Zixuan Wang ${ }^{1}$ \\ ${ }^{1}$ China University of Political Science and Law, Beijing, 102249, China
}

\begin{abstract}
Along with the rapid development of Internet finance in China, the irregularities in Internet finance industry has violated the Internet financial consumer rights at many levels. Learning from domestic and foreign experience, the improvement on the legislation on Internet finance, the financial supervision system and the Internet financial consumer dispute resolution mechanisms should be achieved, so as to enhance the protection of Internet financial consumer rights.
\end{abstract}

\section{Introduction, Basic Concepts and Value of Research}

\subsection{Definition of Internet finance}

Internet finance is a new type of financial business model in which traditional financial institutions and Internet companies use Internet technology and information communication technology to provide funding, payment, investment and information intermediary services. The development model of Internet finance can be roughly divided into seven types, namely online payment, online lending, equity crowdfunding, online fund selling, online insurance, online trust and Internet consumer finance.

\subsection{Definition of financial consumer}

As for the documents of the supervisory authorities, the People's Bank of China Management Measures for the Protection of Financial Consumer Rights and Interests (Trial) issued on May 7, 2013 specifically defined "financial consumers" for the first time: Financial consumers refer to natural persons who purchase and use financial products sold by financial institutions or accept financial services provided by financial institutions within the territory of the People's Republic of China. Although the concept of "financial consumer" has been widely used by the supervisory authorities and scholars in China, it has no clear legal definition. In general, "financial consumer" refers only to natural persons who purchase financialrelated products or services. There are still many controversies in the academic circles regarding the specific connotation and extension of the concept of financial consumers. However, undoubtedly, with the development of Internet finance, the protection of the rights and interests of financial consumer groups has become an important issue.

\subsection{Value of research on Internet financial consumer rights protection}

\subsubsection{Theoretical value of research on Internet financial consumer rights protection}

From an international perspective, most countries have listed financial consumer rights protection as an important goal of financial regulation. In recent years, several practical problems in the field of Internet finance in China has been exposed, and the Chinese government has issued a large number of documents to regulate the industry, calling for the protection of Internet financial consumer rights. Thus, it is necessary for China to supplement relevant legal theories to guide practice and be in line with the world.

\subsubsection{Practical value of research on Internet financial consumer rights protection}

There are a lot of risks behind the development of Internet financial transactions. First of all, Internet financial transactions is virtual and electronic, and there are probably inappropriate manipulations among financial institutions, which would harm the transparency of transaction and increase credit risks. The Internet coverage nowadays is wide, and thus the spread of any risk could be more likely to cause systemic risks. Secondly, with its convenience, low cost and other characteristics, Internet finance serves not only the traditional financial consumers, but also more ordinary people. Their lack of investment knowledge, risk identification and risk tolerance could make them prone to irrational herding. Besides, there are technical risks and legal risks in the field of Internet finance.

In reality, various chaos in the Internet finance industry have damaged the rights and interests of the consumers. 
For example, the bankruptcy of $\mathrm{P} 2 \mathrm{P}$ online lending platforms and the loss of connection with crowdfunding companies have impaired the right to be informed and fair trading right of consumers, thus further jeopardizing other rights and interests of consumers such as their property security rights and personal information protection rights. It has become an urgent need to resolve financial risks, ensure the healthy development of Internet finance, and strengthen the protection of Internet finance consumers.

\section{The Deficiencies of Internet Financial Consumer Rights Protection in China}

\subsection{The lack of legislation on Internet financial consumer protection}

China has no special legislation on Internet finance. Some legal provisions related to consumer protection are scattered in basic legal norms such as civil and commercial law, criminal law, and financial law. However, most of these clauses are biased towards principles, not specific rules. They only take into account consumer protection when specifying business regulations, and thus cannot meet the requirements of strengthening the protection of Internet financial consumer rights. Plus, Law of the PRC on Protection of Consumer Rights and Interests, which is specifically designed to protect consumers, adjusts mainly the relationship between general consumers and operators. Whether financial consumers can apply this law for protection is still controversial, not to mention the protection of Internet financial consumers.

\subsection{Inadequate financial supervision system}

In the 1990s, with the establishment and improvement of the socialist market economic system, the financial structure in China has become increasingly complex. China has adopted the institutional approach to financial supervision, established successively specialized financial regulators in the securities, insurance and banking industry, etc., and set different standards of supervision for different financial products. However, Internet finance has the characteristics of operating across markets and industries. The evolution of modem financial markets had blurred the boundaries between different types of firms and financial products or services, so it is difficult to classify them according to their nature. Thus, the traditional institutional supervision could not be effectively applied to the burgeoning Internet finance industry. Due to the lack of a clear division of supervisory responsibilities, there are often repeated supervision or blind spots in supervision, making it easy for the supervised to evade supervision.

\subsection{Incomplete Internet financial consumer dispute resolution mechanisms}

For Internet financial disputes, the current dispute resolution mechanisms in China mainly include conciliation, mediation, arbitration, and litigation, but these mechanisms have respective shortcomings. The internal conciliation mechanism of Internet financial disputes, that is, the internal complaint channel of Internet financial companies, is incomplete. For the external conciliation mechanism, complaint channels have not been set up by the industry associations. In addition, China lacks specialized mediation agencies, specialized arbitration agencies and specialized courts for the Internet financial industry. At present, China generally regards Internet financial disputes as financial disputes, or as ordinary civil and commercial disputes. Relatively specialized courts such as financial courts and Internet courts are not all-pervading in China.

In recent years, China has tried to establish online dispute resolution mechanisms, and has successively established a nationwide online mediation platform, online financial dispute resolution center, and online court hearing process by Internet courts. However, these are still at a relatively preliminary stage. The online arbitration system has not yet started. Generally, only the initial stage of online litigation, which is online filing, can be reached. The efficiency of online mediation is still low, whose scope of popularization is small, and whose amount of cases accepted is not large.

\section{Referable Domestic and Overseas Experience}

\subsection{Specified Legislation on Internet Finance}

After the US subprime mortgage crisis, many countries learned their lessons so that they gradually strengthened the protection of consumers, reformed the financial supervision system, and paid attention to the legislative regulations in the field of Internet finance in recent years. For example, the Jumpstart Our Business Startups Act (JOBS Act) approved by the United States in 2012 strictly stipulates the financing scale of crowdfunding platforms, and the matters of reporting and disclosure, so as to protect the legitimate rights and interests of financial consumers.

In October 2013, the Financial Conduct Authority (FCA) in the United Kingdom has published a consultation paper, The FCA's Regulatory Approach to Crowdfunding (and Similar Activities) (FCA Consultation Paper CP13/13), which proposed the basic path for the supervision of crowdfunding, mainly regulating loanbased crowdfunding (also known as peer-to-peer lending platforms) and investment-based crowdfunding.

Canada and Taiwan specially formulated legislations on protection of financial consumer rights, which mainly clarify the strict obligations of financial institutions and regulate financial consumer dispute resolution procedures, thereby providing systematic and comprehensive legal protection of the rights and interests of financial consumers.

\subsection{Improved Financial Supervision system}

In the face of the global financial crisis, the financial supervision systems of various countries have undergone 
several changes, and they have gradually converged. Most of the countries have tended to pay more attention to risk control and risk prevention, adopt macro-prudential management, and increase the uniformity, consistency, coordination and transparency of regulatory rules.

According to the analysis report of the Group of Thirty on the post-crisis regulatory framework, The Structure of Financial Supervision: Approaches and Challenges in a Global Marketplace, there are four mainstream supervision models in the world, namely the institutional approach, the functional approach, the integrated approach and the twin peaks approach. The United States chooses an umbrella-shaped regulatory framework that combines the institutional approach and the functional approach; the United Kingdom and Australia adopt the twin peaks approach; Japan and Germany are typical examples of the integrated approach; China is a representative of the institutional approach.

The United States' regulatory framework combines the institutional approach and the functional approach. In the US, multiple regulators divide labor and collaborate with each other. Meanwhile, government regulators let industry associations exercise their supervisory functions, in order to achieve self-discipline in the financial sector. In the Internet financial industry, financial regulators have a clear division of regulatory responsibilities: the US Federal Communications Commission (FCC) and the Federal Trade Commission (FTC) regulate the Internet financial business of non-financial institutions, while those of financial institutions is regulated by the federal and state institutions jointly. At the same time, the state regulators coordinate with self-regulatory organizations and industry associations, and improve relative rules and regulations, so as to strengthen financial supervision at all levels.

According to the twin peaks theory put forward by the British economist Michael Taylor, two parallel goals should be established in terms of financial supervision: One is the goal of prudential supervision, which aims to maintain the stability of the financial system and prevent systemic financial risks. Prudential supervision can be divided into two levels: Macro-prudential is to prevent the occurrence of financial crises from the macro level, while micro-prudential supervision is to prevent the failure of institutions from affecting the financial system through specific supervision of individual institutions. The other is the goal of conduct supervision, which emphasizes to prevent financial consumers from suffering from fraud or other unfair treatment through strengthening the supervision of the conducts of the financial organizations, so as to protect the interests of the financial consumers. Dr. Taylor pointed out that twin peaks supervision could overcome the shortcomings of institutional supervision and functional supervision, prevent overlaps and gaps in supervision, and further eliminate the flaws of integrated supervision by preventing conflicts of regulatory goals, so that the government could achieve the two goals more professionally.

According to the twin peaks theory, it is required to set up two types of regulators instead of an integrated one, namely the prudential regulator and business conduct regulator, to undertake the tasks of two different objectives When there is an independent micro-prudential regulator, it forms a ternary structure of twin peaks supervision, namely the central bank, the micro-prudential regulator and the conduct regulator. When the central bank is fully responsible for micro-prudential supervision and macroprudential supervision, a dual structure of twin peaks supervision is formed.

Since 1990s, the UK changed its integrated supervision model to a ternary structure of twin peaks supervision model. The central bank was upgraded to a macro-prudential regulator; The original integrated regulator "Financial Services Authority" (FSA) was split into the "Prudential Regulation Authority" (PRA), which is responsible for micro-prudential supervision, and the "Financial Conduct Authority" (FCA) responsible for conduct supervision.

\subsection{Developed self-regulatory industry associations}

The self-regulatory industry associations in the UK are very developed, such as the UK Peer to Peer Finance Association (P2PFA), UK Crowdfunding Association (UKCFA), the British Venture Capital Association (BVCA), etc. These associations and government regulators cooperate with and complement each other, so as to jointly perform financial supervision functions, thereby strengthening the supervision of Internet financial enterprises.

Firstly, the self-regulatory industry associations take the lead. The industry associations focus on the regulatory priorities in the Internet finance industry, and initially establish the legality of enterprises joining the industry. Secondly, government supervision continues to follow up. On the basis of industry self-regulation, government supervision bodies further review the market entry conditions of Internet financial institutions, and strictly stipulate the regular disclosure of institutional information, etc.

\section{Suggestions on Internet Financial Consumer Rights Protection in China}

\subsection{Strengthen the relevant legislation on Internet finance}

At present, it is not realistic in China to formulate a special Internet Finance Consumer Protection Law, but it is optional to include Internet finance consumer protection in the overall legislation of financial consumer protection. In addition, each development model of Internet finance such as P2P online lending, online payment, etc., has its own characteristics, so that they are difficult to be incorporated into a unified legislative framework. Thus, it is generally believed that legislation on Internet finance should be conducted separately according to different categories of Internet finance.

In terms of specific systems, legislation related to market entry and exit mechanisms for Internet finance 
institutions should be improved, in order to clarify the entry barriers for various industries. In addition, information disclosure and risk warning systems for Internet finance should be enhanced, so as to protect Internet financial consumers' right to be informed, and to avoid companies operating against the rules by taking advantage of the virtual feature of the Internet and the complexity of technology.

\subsection{Improve the Internet financial supervision system}

The financial supervision system in China is relatively mature. At present, a new financial supervision system has been formed, which consists of Central Bank of the Republic of China, China Banking and Insurance Regulatory Commission (CBIRC), China Securities Regulatory Commission (CSRC), and the Financial Stability and Development Committee under the State Council. Scholars in China have reached consensus on the overall direction of the reform, that is, the transition from sectoral supervision to integrated supervision and twin peaks supervision, and the expansion from the institutional supervision to functional supervision and conduct supervision. In 2017, the Fifth National Financial Work Conference put forward a series of new requirements for financial supervision, which include integrated supervision, responsible supervision, functional supervision and conduct supervision.

In response to the dilemma of China's financial supervision in the macro and micro dimensions, the mainstream opinion in China is to build a "super central bank model" with macro prudence as the core, learning from the twin peaks framework implemented by the UK after the financial crisis. Some scholars advocated to merge the China Banking Regulatory Commission, the China Securities Regulatory Commission, and the China Insurance Regulatory Commission into one financial supervision commission, thus forming the "one Central Bank and one Commission" model, so as to unify and coordinate the work of various regulatory authorities, lead and direct the financial market.

By comparing the regulatory reform measures of the United Kingdom and the United States after the financial crisis, scholars such as Cao Fengqi proposed the idea of establishing an umbrella-shaped financial supervision system with an integrated financial regulator. Corresponding to this, the Development Research Center of the State Council and the Financial and Economic Committee of the National People's Congress advocated to merge the three commissions and establish an integrated financial supervision committee, with a micro-prudential authority and a market and conduct authority being subordinated.

In addition, China should strengthen the capacity of the Internet finance industry associations and use it as a supplement to government supervision. The Internet finance industry associations could serve as a bridge between the regulator and the regulated. On the one hand, when formulating Internet financial policies, the association could feed back the opinions of industry insiders to the regulatory authorities and assist in the implementation of the policies. On the other hand, the associations should pay attention to market trends in the industry, and exert regulatory functions, thus to strengthen industry self-regulation. This method that combines government agencies and self-regulatory organizations helps to effectively supervise the Internet financial institutions and promote stable and standardized development of the Internet financial industry.

\subsection{Establish diversified Internet financial consumer dispute resolution mechanisms}

In order to guarantee the Internet financial consumers' right to claim compensation, China should improve the existing mechanisms and establish diversified Internet financial consumer dispute resolution mechanisms.

The conciliation mechanism should be improved from two aspects. The first is to improve the internal complaint channel of the enterprises, requiring the Internet financial platforms to set up a special dispute handling agency and improve the complaint handling procedures. Moreover, the dispute handling mechanism within the Internet platform should be set as a pre-procedure for the start of other dispute resolution systems to save judicial resources. Second, China could learn from domestic and foreign experience to establish a self-discipline complaint system for industry associations and coordinate with the supervision of administrative authorities.

The mediation, arbitration and litigation mechanisms of Internet financial disputes should be made more professional. China should develop a professional mediation mechanism for industry associations, make full use of the professionalism, flexibility and ease of acceptance of industry associations as private selfregulatory organizations; China should establish a dedicated Internet financial arbitration tribunal, and set up a professional arbitration team, so as to make the rulings meet the professional requirements of the Internet finance industry; In addition, China should gradually establish specialized financial courts and Internet courts in various places, and set up specialized Internet finance courts among them to ensure the professional trial of Internet finance.

Besides, an online dispute resolution mechanism should be established and improved, which should include dispute resolution within the online platform, complaints channels of competent administrative agencies and industry associations, as well as online mediation, online arbitration and online litigation. It is necessary to ensure smooth connection and resource sharing between each mechanism, in order to achieve their efficient and convenient cooperation with each other.

\section{Conclusion}

The development of Internet finance industry in China is becoming more and more in line with rules. In order to better protect the rights and interests of Internet finance consumers, China should strengthen special legislations in the field of Internet finance. On the basis of the existing 
"one Central Bank, two Commissions and one Committee" institutional financial supervision system, China should strengthen integrated supervision, responsible supervision, functional supervision and conduct supervision. Besides, diversified Internet financial consumer dispute resolution mechanisms should be established.

\section{References:}

1. Lin Ling. Research on Legal Issues of China's Financial Consumer Rights Protection[D]. Liaoning University.

2. Qu Yifan. A Comparative Study on Financial Consumer Protection Legal Systems[D]. China University of Political Science and Law.

3. Xu Huizhi. Research on Internet Financial Consumer Protection[D]. 2016.

4. Zhang Yuanyuan. Exploring the Path of Financial Consumer Protection Under the "One Bank, One Committee and Two Commissions" Supervision System[D]. Shandong University, 2019.

5. Wei Gejun. Thoughts on the Reform of Financial Industry in the New Era in China[J]. Tribune of Study, 2020(01):38-45.

6. Yin Haiyuan, Wang Panpan. The Status Quo and System Construction of the Internet Financial Supervision in China[J]. Finance Economics, 2015, 000(009):12-24.

7. Zhang Ni. Research on Legal Problems of Internet Financial Supervision in China[D]. Hebei University of Economics and Business, 2019.

8. Long Dan. An Analysis of the Long-term Mechanism of Internet Financial Supervision[J]. Finance Economy, 2019(22).

9. $\mathrm{Lu} \mathrm{Li}$, Tian Ye. International Model and China's Choice in Financial Regulatory Framework-A Deconstructive Analysis[J]. Social Science Research, 2019, 000(001):72-85.

10. Group of Thirty. The Structure of Financial Supervision: Approaches and Challenges in a Global Marketplace.

11. Wu Yun, Zhang Tao. Financial Supervision Reform after the Crisis: Dual Structure of the "Twin Peaks Supervision" Model[J]. ECUPL Journal,2016,19(03):106-121.

12. Feng Zhaoyang. Research on Internet Financial Dispute Resolution Mechanism[D]. 2019. 